\title{
What factors affect the choice of accounting as a career? The case of Romania
}

\author{
Cristina-Florina Țicoi ${ }^{\mathrm{a}, 1}$ and Nadia Albu \\ ${ }^{a}$ Bucharest University of Economic Studies, Romania
}

\begin{abstract}
This paper aims to examine the motivations of choosing accounting as a profession in Romania. The paper is motivated by the recent interest at the international level in understanding the trends in the accounting profession. The theoretical tension arises from the Romanian context given the significant challenges for the profession triggered by the transition from communism to a market-based economy. We use a survey-based approach. The sample consists of 112 students undertaking accounting courses both for Bachelor's Degree or Master Courses at two Romanian universities and 125 professionals belonging to The Body of Expert and Licensed Accountants of Romania. We find that the most important group of factors in choosing the accounting career includes the intellectual motivation, followed by relational and financial incentives. There are a few significant differences between men and women, and between students and professionals. When differences occur, women manifest a lower level of motivation, and professional accountants a higher level of motivation. The results show the driving forces behind the composition of the accounting profession and inform the sociology of the profession, of interest for both academia and practice. Our study contributes to an emerging national and international literature investigating the accounting profession by providing concrete information about the motivations of choosing it in Romania.
\end{abstract}

Keywords: accounting profession, motivation, Romania

\section{JEL codes: M41}

\footnotetext{
${ }^{1}$ Corresponding author: Cristina-Florina Țicoi, Doctoral School of Accounting, Bucharest University of Economic Studies, Tache Ionescu Street no.11, floor 1, Sector 1, Bucharest, Romania, tel. (+40.726.000.114), email address: cristina@ cristinaticoi.ro
} 


\section{Introduction}

This paper explores the motivation of choosing accounting as a profession in the context of Romania, a former communist country. The Romanian context is particularily interesting to study, and has the opportunity to offer relevant insights for other emerging economies, because of the transition towards a market-based economy and the professional and social transformations around it. We thus respond to recent calls (Brock, 2016) to investigate the accounting profession in an emerging economy.

The factors motivating the choice of any career are important to be investigated, to assess the desirability of the profession, to understand its image in society and to assess if the right people are attracted to the profession. Consequently, several studies (e.g., Germanou et al., 2009; Manganaris \& Spathis, 2015; McDowall \& Jackling, 2010; Sugahara et al., 2009) investigate in various countries the motivating factors for choosing an accounting career. We complement this literature by investigating the motivating factors in the context of Romania. Studies on the accounting profession, in terms of image, skills, roles, increased in number in the last decade. However, there is a limited focus on the choice of the accounting profession as a career, especially given the recent opportunities and challenges raised for the profession by the current economic environment (ACCA, 2012).

We survey students and professionals in order to uncover their motivations in selecting accounting as a profession. The data was collected at the beginning of 2017 and includes demographic data and measures of the motivation in choosing accountancy profession in seven areas: education, personal, financial, social, intellectual, relational and creative.

We find that, overall, the respondents consider the intellectual motivations as the most important group of factors: intelligence, intellectual satisfactions, wide possibilities for further professional developments. Relational and financial variables were scored on the next places as motivations for the accountancy career. We find few significant differences between men and women, and between students and professionals. More specifically, we find that difficulty of the exams, the opportunity costs, personal skills, future development opportunities, and creativity represent a lower motivation for women than for men. Some of the personal and relational groups of factors represent a higher motivation for professionals than for students. Moreover, we find that while most of the factors are correlated with age and experience, the results are surprising. As such, as expected, the financial factors and intellectual ones are more important for the young generation, unline the relational and creativity factors (positively correlated with age) or social and relational factors (not correlated with age). 
The study is organized as follows: a literature review on the factors motivating the choice of accounting as a career and on the accounting profession in a former communist context is followed by the description of the research method. Data analysis follows, and a conclusion part ends the paper.

\section{Literature review}

\subsection{Incentives for choosing accounting as a profession}

The image of the accounting profession and how new members are attracted represent a topic of interest for different researchers in countries all over the world (Albu et al., 2014; McDowall \& Jackling, 2010; Simons et al., 2003; Sugahara et al. 2009). Most of the studies conducted in this area utilize data collected through surveys, mainly on students and accountants, to identify their perception of the profession, its attractiveness and public desirability.

Various factors have been identified as potentially influencing the choice of the accounting profession. Simons et al. (2003) present an overview of the studies investigating the factors impacting the choice of the accounting career. They review 21 studies published up to the date of their study (up to year 2002) and categorize the factors in two groups: student expectations and student background. The student expectations factors include the potential earnings, the availability of employment, the social status and prestige, and the intellectual challenge. The student background factors comprise previous work experience, aptitude for the subject, parents, teachers or peers (as important referents) influence. More recent studies provide more indepth and nuanced findings.

One of the factors identified in prior studies to guide the choice of a profession is its public image (Holland, 1966, 1973 cited in McDowall \& Jackling, 2010), with direct impact on the perceived social status and prestige. A profession's image in society, or stereotype, is a part of the public's attitude and therefore plays a role in the selection of those who intend to become a part of it. The traditional stereotype is that accountants are bean counters, boring, conservative, obsessed with numbers (Carnegie \& Napier, 2010; Hunt et al., 2004; Jeacle, 2008). This traditional image might be unappealing for young people to become members of the profession. Some studies (Marriott \& Marriott, 2003) confirm this, while others (Sugahara et al., 2009) do not find that stereotype is significantly influencing the decision. However, it appears that people selecting the profession have a better image about accounting. For example, Hunt et al. (2004) survey American accounting and non-accounting students and find that accounting students hold a better image than other students in the economic field. Sugahara et al. (2009) survey Japanese students and find that students who did not major in accounting are more reluctant to become accountants. 
Another important factor in the decision is prior exposure to accounting. To some extent, this exposure allows people to check how the stereotype fits with their experience with accounting. Hunt et al. (2004) survey American students and find that accounting classes generally have a negative impact on the image held by students about accounting and accountants. Marriott and Marriott (2003) find the same result in the UK context, and Sugahara and Boland (2006) find for Japan that accounting students have more positive perceptions about accounting carrers compared to non-accounting students. Sugahara et al. (2009) suggest that in the Japanese context early exposure to accounting during studies contributes to higher attractiveness to the field.

Some of these findings are validated by Manganaris and Spathis (2015) for the Greek context. They survey 231 undergraduate students to investigate the relationship between students' perceptions about courses in accounting and interest in accounting profession. In this purpose, surveys were conducted at the beginning and at the end of the semester. Results show that at the beginning of the course students were influenced by the traditional accountant stereotype. These perceptions improved after completing the accounting course. Therefore, exposure to accounting increased its attarctiveness. However, this is dependent on the quality of education and educators' attitudes and pedagogical tools utilized. Moreover, the study finds that students interested in the profession held a better image than the rest of the students, both before and after the accounting class.

Contrary to this study, McDowall and Jackling (2010) find that exposure to accounting does not improve the attractiveness of the profession in students' eyes. They survey 131 Australian and international undergraduate students and find that exposure to accounting reinforced traits associated with the traditional stereotype, such as memorization, rule and number oriented. However, their results are different between national and international students. The comparison between the two groups of students reveals that local students are more appreciative regarding the profession than the international students. Differences between countries in terms of the image of the profession held by students and their intentions to follow a career in accounting have been documented by other studies as well. For example, Germanou et al. (2009) investigate the differences between Malaysian and English students. English students perceive that the accounting profession provides economic rewards and contributes to business and society, while Malaysian students appreciate the job security and the interesting nature of the profession. These findings suggest that the attitude towards the profession is socially and locally constructed and therefore studies in various contexts are required.

Another factor with a potential impact on the career choice is the personality of students. The studies on stereotypes cover to a large extent the personality features as well (Albu, 2013). In their study of accountants characters in films, Dimnik and Felton (2006) extensively cover personality features ranging from personal 
characteristics (sincerity, kindness, courage, humor, ambition, optimism, luck), to their attitude in public (civility, power, activity, demeanor), intellect (intelligence, sophistication, skillful) to their physical appearance (age, sexy, glasses, clothes, fashion, outlook, attire, weight, height, hair). The authors identify six factors regrouping these characteristics: confidence, warmth, vitality, occupational status, outlook and appearance.

Andon et al. (2010) investigate in Australia the personality preferences of accounting and non-accounting graduates. They utilize a research instrument derived from the work of Carl Jung and his successors, including the following pairs of personality traits: sensing vs intuition, thinking vs feeling, extroversion vs introversion, and judging vs perceiving. They find that the common aspect between the accounting and non-accounting graduates who enter the accounting profession is the personality preferences.

\subsection{The accounting profession in Romania - an overview}

The development of the accounting profession in Romania was influenced by the development of accounting itself. Given the tumultuous history of the Romanian teritories, accounting started to develop later than in Western Europe, especially after the middle of the nineteenth century (Calu, 2005). The first body of the accounting profession was created in 1921, but dismantled in 1951 when the communist regime was instated (Calu, 2005; Albu, 2013).

The communist times had a major impact on the accounting profession, including its role in society, attractiveness and skills expectations, in Romania as well as in the region (Albu, 2013; Bunget et al., 2009; Calu, 2005; Seal et al., 1996; Sucher et al., 1996; Tobór-Osadnik et al., 2013). For example, Seal. et al. (1996: 486) citing Bailey (1988) notice that ,the occupational status and relative remuneration of accountants in socialist countries was generally low", accountants being mainly bookkeepers socially ranked ,along side technicians such as punch card operators”.

Tobór-Osadnik et al. (2013) discuss the traits of the accountant influenced by communism using the 'homo sovieticus' concept. The main traits of the 'homo sovieticus' are: submission to authorities, lack of individuality, not making important decisions, lack of thinking skills, expectation that authorities "will take care of all matters, show the way" (p. 23). Tobór-Osadnik et al. (2013) investigate the personality traits of Polish accountants and find that these traits persist even after the fall of communism.

Influences from the communist times were documented in the Romanian case as well (Albu, 2013). Even if accountants were expected to play a significant role in the economic reforms (Mustață et al., 2011), features such as pessimistic, anxious, boring and with low-level jobs (Albu \& Albu, 2009) or rigor, correctness, precision 
(Istrate, 2009) are still persistent. Other studies (Albu \& Gîrbină, 2011; Albu et al., 2011; Albu et al., 2014) investigate the image students hold about accountants, since it influences the career's choice. students see the accountants as introverted and accounting as concrete activity characterized by routine and certainty. It results that most students associate accounting with bookkeeping. The fact that they see accounting as introverted will create difficulties to the development of communication skills necessary for the modern tasks of the accountant and will attract wrong people in the domain. Students having a job in accounting see it as governed by established rules and facts (probably because most of them act within financial accounting domain and are involved more in bookkeeping activities) but also a concrete, logical and fascinating activity which is a positive aspect for their future development as professionals.

Albu et al. (2014) investigate both the role and professional skills of the accountants as profession and their actual perceptions about the profession and motivations in choosing accountancy as profession. Results show that the perception of the students is that the most important roles that the accountants are financial reporting and financial administration and attribute less importance to the role of "consultant" or "analyst for the management". Regarding the motivation in choosing the accountancy as career, the respondents consider as first argument, the importance of the profession in the society" followed by "intellectual satisfactions" and the third "financial satisfactions".

Existing research is limited in terms of factors affecting career choice. Prior research suggests that the traditional image of accountants persists, students are affected and attracted to the profession by this image. We therefore investigate in more depth the factors affecting the choice of accounting as a career.

\section{Research methodology}

For the purpose of this study we surveyed accounting students and accounting professionals. We elaborated a questionnaire with two sections, the first one containing demographic questions (gender, age, place of residence and experience), and the second section containing questions about the motivation in choosing accounting profession.

Based on prior studies investigating the motivation for choosing the accounting profession (McDowall \& Jackling, 2010; Germanou et al., 2009; Sugahara et al., 2006) we developed an instrument with potential factors serving as motivators, grouped in seven areas: education, personal, financial, social, intellectual, relational and creative factors. 
Respondents were asked to rate on a 5-point Likert scale (from $1=$ strongly disagree to $5=$ fully agree) the importance for their person of the factors in selecting the profession. A total number of 21 factors was investigated.

The survey was administered both on line using Google Forms and on paper, to maximize the response rate. Questionnaires were filled in the first months of 2017. In case of the students we delivered the questionnaires during accounting classes and for the professionals during courses and various meetings of The Body of Expert and Licensed Accountants of Romania (CECCAR).

We obtained a total of 248 questionnaires, of which 13 were discarded for being incomplete, with too many answers missing. Therefore, we had 235 usable responses, of which 112 students and 125 professionals. The students were undertaking accounting courses both for Bachelor's and Master's Degrees, in two universities: 52 students are from the Bucharest University of Economic Studies, and 60 are from Ovidus University in Constanța. From the professionals, 18 belong to the Bucharest Branch of the Body and 107 to other Branches in Romania. The demographic data are shown in Table 1 and Table 2.

Table 1. Demographic data - gender and geographic diversity

\begin{tabular}{lcccccc}
\hline & Students & N\% & Professionals & N\% & Total & N (\%) \\
\hline Gender & 11 & 9.82 & 48 & 38.40 & 59 & 24.89 \\
Male & 101 & 90.18 & 77 & 61.60 & 178 & 75.11 \\
Female & 112 & & 125 & & 237 & \\
Total & & & & & & \\
Residence & 52 & 46.43 & 18 & 14.40 & 70 & 29.54 \\
Bucharest & 50 & 53.57 & 107 & 85.60 & 167 & 70.46 \\
National & 60 & & & & & \\
Total & 112 & & 125 & & & \\
\hline
\end{tabular}

Table 1 shows a balanced geographic diversity of the sample. Moreover, the table reflects the fact that the Romanian profession is mostly composed of women (Albu, 2013; Istrate, 2009). Statistics show that about two thirds of the CECCAR members are women (Albu, 2013). This trend is reflected in the gender composition of the students population, with significant differences from one cohort to another. Table 2 reports the respondents' age and experience. 
Table 2. Demographic data - experience and age

\begin{tabular}{lcc}
\hline & Students & Professionals \\
\hline Experience (years) & & \\
Minimum & 0 & 0 \\
Maximum & 15 & 50 \\
Median & 0 & 15 \\
Mean & 0.62 & 17.48 \\
Age (years) & & \\
Minimum & 20 & 22 \\
Maximum & 49 & 83 \\
Median & 22 & 46 \\
Mean & 23.05 & 46.73 \\
\hline
\end{tabular}

Most of the students surveyed do not have work experience (median 0, mean 0.62), while the professionals have on average 17.48 years of work experience. Moreover, we surveyed very young (minimum 22 years) and also senior (maximum 83 years) professionals, in order to be able to check for the impact of changes in the economic environment on the choice of accounting as a career.

\section{Results}

\subsection{Motivations for choosing the accounting profession}

Respondents were asked to assess on a 5 point Likert scale the importance of various factors in choosing accounting as a profession. Table 3 reports the values for the entire sample.

Table 3. Motivations for choosing accounting as a profession

\begin{tabular}{lccc}
\multicolumn{1}{c}{ Variables } & Mean & Median & Sd. Dev. \\
\hline Intellectual_intelligence & 4.008 & 4.000 & 1.228 \\
Intellectual_satisfactions & 3.916 & 4.000 & 1.183 \\
Intellectual_specialization & 3.848 & 4.000 & 1.198 \\
Intellectual_memorization & 3.489 & 4.000 & 1.209 \\
Intellectual_routine & 2.924 & 3.000 & 1.293 \\
Intellectual_average & $\mathbf{3 . 6 3 7}$ & $\mathbf{3 . 8 0 0}$ & $\mathbf{0 . 8 4 6}$ \\
Relational_communication & 3.561 & 4.000 & 1.232
\end{tabular}




\begin{tabular}{lccc}
\hline \multicolumn{1}{c}{ Variables } & Mean & Median & Sd. Dev. \\
\hline Relational_team & & & \\
Relational_comfort & 3.637 & 4.000 & 1.155 \\
Relational_average & 3.650 & 4.000 & 1.081 \\
Financial_satisfaction & $\mathbf{3 . 6 1 6}$ & $\mathbf{3 . 6 6 7}$ & $\mathbf{0 . 9 2 9}$ \\
Financial_job & 3.481 & 3.000 & 1.072 \\
Financial_integration & 3.688 & 4.000 & 1.195 \\
Financial_average & 3.641 & 4.000 & 1.208 \\
Social_respect & $\mathbf{3 . 6 0 3}$ & $\mathbf{3 . 6 6 7}$ & $\mathbf{0 . 9 9 0}$ \\
Social_benefits & 3.540 & 4.000 & 1.195 \\
Social_average & 3.582 & 4.000 & 1.175 \\
Personal_teachers & $\mathbf{3 . 5 6 1}$ & $\mathbf{4 . 0 0 0}$ & $\mathbf{1 . 0 5 3}$ \\
Personal_professionals & 3.025 & 3.000 & 1.292 \\
Personal_friends & 3.030 & 3.000 & 1.668 \\
Personal_skills & 2.295 & 2.000 & 1.422 \\
Personal_average & 4.000 & 5.000 & 1.279 \\
Creativity & $\mathbf{3 . 0 8 8}$ & $\mathbf{3 . 0 0 0}$ & $\mathbf{0 . 7 9 8}$ \\
Educational_access & $\mathbf{2 . 6 8 8}$ & $\mathbf{3 . 0 0 0}$ & $\mathbf{1 . 3 7 9}$ \\
Educational_exams & 2.506 & 2.000 & 1.377 \\
Educational_costs & 2.186 & 2.000 & 1.228 \\
Educational_average & 2.338 & 2.000 & 1.247 \\
\hline & $\mathbf{2 . 3 4 3}$ & $\mathbf{2 . 3 3 3}$ & $\mathbf{1 . 1 1 7}$ \\
\hline & & & \\
& & & \\
& & &
\end{tabular}

Table 3 shows that the most important group of factors motivating the choice of accounting as a profession is the one with intellectual motivations. In order to analyze the intellectual motivations, five variables were identified as relevant in choosing the profession: intelligence, intellectual satisfactions, wide possibilities for further professional developments, rule-memorizing, and routine. The highest mean score (4.008) was obtained for the intelligence factor which resulted to be the most important factor in choosing accounting as a profession. This result is consistent with the results of another study conducted in a different institutional context (Sugahara \& Boland, 2006). The study finds that students rank very high the intellectual stimulation provided by the profession, which represents as well a motivating factor for the choice of accounting as a career. On the other hand, out results contrast with the traditional image of accountants that involves dullness and lack of creativity (Carnegie \& Napier, 2010; Hunt et al., 2004; Jeacle, 2008) and with the communist traits involving low thinking skills (Tobór-Osadnik et al., 2013). Consequently, these results might be an indication of a change in the Romanian accounting profession. 
On the second place of importance are the relational factors; three variables were identified: interactional perspectives and communication, team work and work conditions (comfort). The working comfort registered the highest mean score (3.650) among these factors. The importance of this group of factors is in line with the results of previous studies (Sugahara \& Boland, 2006) showing that communication skills are important for the profession.

Many universities advertise their accounting programs by using statistics about the financial benefits and job security in accounting. These are the main factors we considered in this category, along with professional opportunities. However, this group of motivating factors resulted to be the third classified. Our results confirm that the financial aspects are important when choosing the accounting profession (Germanou et al., 2009), but they are not the most important ones.

Regarding the social plan, the respondents were asked to score two aspects in choosing accounting as a profession: accounting is a well-respected profession that offers an important position in the society and that accountants contribute to the society. The mean scores 3.540 and 3.582 shows that we can consider the social aspects as motivating factor for choosing the profession, consistent with other studies (Germanou et al., 2009).

In the personal plan, we asked the respondents to scale motivations of choosing the profession because of the teachers appreciations, known professionals as models, choice made in the group of friends or based on the personal skills. The respondents disagreed with the fact that the motivation of choosing the profession was a ,,peer choice', with a mean score of 2.295. This result is consistent with the conclusions of another study about the attitudes towards the accounting profession (McDowall \& Jackling, 2010). Personal skills were considered to be the most important motivation from this set of questions (mean 4.000) followed by the teachers appreciations (mean 3.025) and by the professionals models (mean 3.030).

Creativity and education are the factors perceived as motivating the least the choice of accounting as a career. In the educational plan, three questions have been addressed to the respondents asking to evaluate the difficulty of the access exams, of the graduation exams, and the costs that the accounting studies. The results suggest that the respondents disagree on the fact that they have chosen the profession because the exams were easy and the costs were low.

\subsection{Differences between gender and professional groups}

We then perform a more in-depth analysis of responses, by comparing men and women's responses, and students with professionals. Non parametric tests were used to determine differences in mean motivations in choosing the profession between students and professionals and between males and females. 
What factors affect the choice of accounting as a career? The case of Romania

Table 4. Differences between men and women and between students and professionals' motivations

\begin{tabular}{|c|c|c|c|c|}
\hline \multirow{2}{*}{ VARIABLES } & \multicolumn{2}{|r|}{ GENDER } & \multicolumn{2}{|c|}{ TYPE } \\
\hline & Men & Women & Students & Professionals \\
\hline Educational_access & 2.525 & 2.500 & 2.571 & 2.448 \\
\hline Educational_exams & 2.458 & $2.095^{*}$ & 2.036 & 2.320 \\
\hline Educational_costs & 2.576 & $2.258^{*}$ & 2.277 & 2.392 \\
\hline Educational_average & 2.520 & 2.290 & 2.295 & 2.387 \\
\hline Personal_teachers & 3.034 & 3.022 & 2.946 & 3.096 \\
\hline Personal_profession & 3.271 & 2.949 & 2.696 & $3.328^{* * *}$ \\
\hline Personal_friends & 2.627 & $2.185^{* *}$ & 2.018 & $2.544^{* * *}$ \\
\hline Personal_skills & 4.271 & $3.910^{*}$ & 4.036 & 3.968 \\
\hline Personal_average & 3.301 & $3.017^{* * * *}$ & 2.924 & $\mathbf{3 . 2 3 4}^{* * * *}$ \\
\hline Finance_satisfaction & 3.508 & 3.472 & 3.580 & 3.392 \\
\hline Finance_job & 3.644 & 3.702 & 3.786 & 3.600 \\
\hline Finance_integration & 3.780 & 3.596 & 3.741 & 3.552 \\
\hline Financial_average & 3.644 & 3.590 & 3.702 & 3.515 \\
\hline Social_respect & 3.373 & 3.596 & 3.616 & 3.472 \\
\hline Social_benefits & 3.763 & 3.522 & 3.482 & 3.672 \\
\hline Social_average & 3.568 & 3.559 & 3.549 & 3.572 \\
\hline $\begin{array}{l}\text { Intellectual__ } \\
\text { Intelligence } \\
\text { Intellectual__ }\end{array}$ & 4.119 & 3.972 & 4.080 & 3.944 \\
\hline Satisfactions & 4.017 & 3.882 & 4.000 & 3.840 \\
\hline $\begin{array}{l}\text { Intellectual_ } \\
\text { Specialization }\end{array}$ & 4.102 & $3.764^{*}$ & 3.813 & 3.880 \\
\hline $\begin{array}{l}\text { Intellectual_- } \\
\text { Memorisation }\end{array}$ & 3.593 & 3.455 & 3.563 & 3.424 \\
\hline Intellectual_routine & 2.983 & 2.904 & 3.125 & $2.744^{* *}$ \\
\hline $\begin{array}{l}\text { Intellectual_ } \\
\text { Average } \\
\text { Relational_ }\end{array}$ & 3.763 & 3.596 & 3.716 & 3.566 \\
\hline Communication & 3.814 & $3.478^{* *}$ & 3.196 & $3.888^{* * *}$ \\
\hline Relational_team & 3.780 & 3.590 & 3.482 & $3.776^{* *}$ \\
\hline Relational_comfort & 3.814 & 3.596 & 3.696 & 3.608 \\
\hline Relational_average & 3.802 & $\mathbf{3 . 5 5 4}^{*}$ & 3.458 & $3.757^{* *}$ \\
\hline Creativity & 3.407 & 3.079* $^{*}$ & 2.866 & $3.424^{* * * *}$ \\
\hline
\end{tabular}

Vol. 17, No. 1 
The analysis suggests few statistical significant differences between gender and professional types. The factors statistically different between gender types include the difficulty of the exams, the opportunity costs, personal skills, future development opportunities, and creativity. In all cases, these factors represent a lower motivation for women than for men. On the other hand, some of the personal and relational groups of factors represent a higher motivation for professionals than for students.

\subsection{Correlations with age and experience}

Romania provides an interesting context to investigate a change in the factors motivating the choice of accounting as a profession. We are able to investigate this issue by running a correlation test between age/experience and the motivating factors for choosing the accounting profession.

Table 5. Correlation analysis between age/experience and the factors motivating the choice of accounting as a career

\begin{tabular}{|c|c|c|c|c|c|c|c|c|c|}
\hline Variables & (1) & (2) & (3) & (4) & (5) & (6) & (7) & (8) & (9) \\
\hline (1) Age & 1 & & & & & & & & \\
\hline (2)Experience & $0.866^{\text {*** }}$ & 1 & & & & & & & \\
\hline (3)Educational factors & 0.025 & 0.037 & 1 & & & & & & \\
\hline (4) Personal factors & $0.184^{* * *}$ & $0.127^{*}$ & $0.322^{* * *}$ & 1 & & & & & \\
\hline (5) Financial factors & $-0.115^{*}$ & -0.098 & 0.075 & $0.294^{* * *}$ & 1 & & & & \\
\hline (6) Social factors & 0.008 & 0.004 & 0.082 & $0.341^{* * *}$ & $0.585^{* * *}$ & 1 & & & \\
\hline (7) Intellectual factors & $-0.136^{* *}$ & -0.101 & 0.026 & $0.218^{* * * *}$ & $0.537^{* * * *}$ & $0.611^{* * * *}$ & 1 & & \\
\hline (8) Relational factors & $0.177^{* * * *}$ & $0.146^{* *}$ & 0.076 & $0.361^{* * *}$ & $0.408^{* * * *}$ & $0.526^{* * * *}$ & $0.507^{* * * *}$ & 1 & \\
\hline (9) Creativity & $0.217^{* * *}$ & $0.176^{* * *}$ & 0.101 & $0.238^{* * *}$ & $0.157^{* *}$ & $0.326^{* * *}$ & $0.254^{* * *}$ & $0.437^{\text {*** }}$ & 1 \\
\hline
\end{tabular}

Our correlation (Pearson) analysis suggests that for younger respondents financial and intellectual factors are more important than for older respondents, while personal, relational, and creativity factors are more important for older respondents and for the ones more experienced. These results confirm the perception that the accounting profession provides good work opportunities in the current environemnt and financial stability. The results suggesting that relational and creativity factors are more important for the older respondents are surprising, given the expected change in the profession. During communism, the profession was reduced to bookkeeping, thus implying less creativity and social relationships (Albu, 2013). Our results suggest that the younger generation do not perceive the profession as being changed, more creative and social. This means that either the stereotype (or even the profession) remains close to the traditional one, or, if the profession slowly chnaged, the relational and creativity factors are not much more important in choosing the profession. Both of these explanations may raise the question if the right people are attracted to the accounting profession. 
Educational and social factors are not correlated with age or experience. Since the profession was socially diminshed during communism (Calu, 2005), we expected to see signs of imporvement. This results suggest, again, either a slow improvement or, if improved, a factor not important for the respodents.

\section{Conclusion}

This study examines the motivations of choosing accounting as a profession in Romania. We investigate the importance of seven groups of factors identified as determinants in choosing accounting as a career: educational factors, personal factors, financial factors, social factors, intellectual factors, relational and creative factors. We find from a sample of students and professional that the most important group of factors includes the intellectual motivations for selecting the accounting profession. This results is consistent with the findings of other studies (Sugahara \& Boland, 2006).

On the second place of importance are the relational plan factors such as interactional perspectives and communication, team working and work conditions (comfort), again in line with prior research (Germanou et al., 2009). Variables such as economic benefits, job security and opportunities grouped as financial motivations in choosing accountancy as profession, were ranked as third category of motivating factors.

Our findings are of interest for the accounting profession and academia, being intended to guide the selection of efficient instruments for improving the image and attractiveness of the accounting profession. We particularly draw attention to the positive correlation between age and the relational and creativity factors, suggesting that the younger generation does not appreciate to a higher extent the improvements and opportunities in the accounting profession in the current environment. Corroborating these results with those of prior studies suggesting that the traditional stereotype persists in Romania (Albu \& Albu, 2009; Albu, 2013) and in the region (Tobór-Osadnik et al., 2013), we draw attention to the importance of the factors motivating the choice of the accounting as a profession and of the accounting's image in society in driving these motivations.

\section{Acknowledgements}

A prior version of this paper was presented at the 12th edition of the International Conference Accounting and Management Information Systems (AMIS 2017) held at the Bucharest University of Economic Studies, on June 7-8, 2017, in Bucharest, Romania and at the IAAER conference Financial Reporting and Auditing: Challenges and Opportunities for Accounting Researchers and Educators, held in 
Cracow on September 26-27, 2017. We thank reviewers and participants for their feedback.

\section{References}

ACCA (2012) 100 drivers of change for the global accountancy profession, ACCA Report

Albu, C.N. \& Albu, N. (2009) "Consideraţii generale privind imaginea contabilului în societate" [General considerations regarding the accountant's image in society”, Contabilitatea, Expertiza şi Auditul Afacerilor [Accounting and Business Expertise and Audit], no. 4:7-11

Albu, C.N. \& Gîrbină, M. ( 2011) "How important are stereotypes in teaching accounting - Some evidence from an emerging economy", 4th International Conference of Education, Research and Innovation, 14-16 November, Madrid

Albu, N., Albu, C., Gîrbină, M.M. \& Sandu, I. (2011) "Students perceptions of accounting and accountants: A stereotypical analysis", Globalization and Higher Education in Economics and Business Administration", GEBA, 20-22 Octomber, Iaşi, Romania

Albu, N., Feldioreanu, I.A., Drug, R.E., Florea, O.A., Gherge, R.G. \& Ghițescu, D. (2014) "Percepția studenților asupra imaginii profesiei contabile în România" [Students' perception on the accounting profession's image in Romania], Contabilitatea, expertiza și auditul afacerilor [Accounting and Business Expertise and Audit], vol. 3: 5-10

Albu, N. (2013) A Romanian perspective on the image and the role of the accounting profession, Editura ASE

Andon, P., Chong, K. M. \& Roebuck, P. (2010) "Personality preferences of accounting and non-accounting graduates seeking to enter the accounting profession", Critical Perspectives on Accounting, vol. 21: 253-265

Brock, D.M. (2016) "Professionals and their workplaces in emerging markets - a research agenda", International Journal of Emerging Markets, vol. 11: 460-472

Bunget, O.C., Farcane, N., Dumitrescu, A.C. \& Popa, A. (2009) "The accounting profession and professionist in Romania"; MPRA Paper, no.18408, http://mpra.ub.uni-muenchen.de/18408/

Calu D.A. (2005) Istorie şi dezvoltare privind contabilitatea din România [History and development regarding Romanian accounting], Bucureşti: Economică

Carnegie, G.D. \& Napier, C.J. (2010) "Traditional accountants and business professionals: Portraying the accounting profession after Enron", Accounting, Organizations and Society, vol. 35: 360-376 
Dalton, D.W., Buchheit, S., Jeffrey, J. \& McMillan, J.J. (2014) “Audit and tax career paths in public accounting: an analysis of student and professional perceptions", Accounting Horizons, vol. 28: 213-231

Dimnik, T. \& Felton, S. (2006) "Accounting stereotypes in movies distributed in North America in the twentieth century", Accounting, Organizations and Society, vol. 31:129-155

Friedman, A.L. \& Lyne, S.R. (2001) "The beancounter stereotype: towards a general model of stereotype generation", Critical Perspectives on Accounting, vol. 12:23-451

Germanou, E., Hassall, T. \& Tournas, Y. (2009) “Students' perception of accouting profession: work value approach", Asian Review of Accounting, vol. 17: $136-148$

Hunt, S.C., Falgiani, A.A. \& Intrieri, R.C. (2004) "The nature and origins of students' perceptions of accountants", Journal of Education for Business, vol. 79 , no. 3: 142-148

Istrate, C. (2009) "Despre cum este văzută contabilitatea dinăuntrul şi dinafara profesiei" [On how accounting is perceived from withi and outside the profession], in Informarea financiar-contabilă în condiţii de criză: 15 ani de la implementarea noului sistem contabil în România [Financial accounting reporting in crises conditions: 15 years from the implementation of a new accounting system in Romania], Iaşi: Ed. Univ. A.I.Cuza, pp. $124-137$

Jackling, B. \& De Lange, P. (2009) "Do accounting graduates skills meet the expectations of employers? A matter of convergence or divergence", Accounting Education: An International Journal, vol. 18: 369-385

Jeacle, I. (2008) "Boyond the boring grey: The construction of the colourful accountant", Critical Perspectives on Accounting, vol. 19: 1296-1320

Manganaris, P. \& Spathis, C. (2015) "Greek students' perceptions of an introductory accounting course and the accounting profession", Advances in Accounting Education: Teaching and Curriculum Innovations, vol. 13: 59-85

Marriott, P. \& Marriott, N. (2003) "Are we turning them on? A longitudinal study of the undergraduate accounting students attitudes towards accounting as a profession", Accounting Education, vol. 12: 113-133

McDowall, T. \& Jackling, B. (2010) "Attitudes towards the accounting profession: an Australian perspective", Asian Review of Accounting, vol. 18: 30-49

Mustață, R., Fekete, S., Matiş, D. \& Bonaci, C.G. (2011) "Motivating accounting professionals in Romania. Analysis after five decades of communist ideology and two decades of accounting harmonization", Accounting and Management Information Systems, vol. 10: 169-201

Seal, W., Sucher, P., \& Zelenka, I. (1996) "Post-socialist transition and the development of an accountancy profession in the Czech Republic", Critical Perspectives on Accounting, vol. 7: 485-508 
Simons, K.A., Lowe, D.R. \& Stout, D.E. (2003) "Comprehensive literature review: factors influencing choice of accounting as a major", Proceedings of the 2003 Academy of Business Education Conference, http://www.abe. villanova.edu/proc2003/simons.pdf

Sucher, P., Seal, W. \& Zelenka, I. (2003) "True and fair in the Czech Republic: a note on local perceptions", European Accounting Review, vol. 5: 545-557

Sugahara, S. \& Boland, G. (2006) "Perceptions of the certified public accountants by accounting and non-accounting tertiary students in Japan", Asian Review of Accounting, vol. 14: 149-167

Sughara, S., Hiramatsu, K. \& Boland, G. (2006) "The factors influencing accounting school students career intention to become a Certified Public Accountant in Japan", Asian Review of Accounting, vol. 17: 5-22

Tobór-Osadnik, K., Wyganowska, M., \& Kabalski, P. (2013) "International Financial Reporting Standards vs. homo sovieticus personality - the case of Poland", International Journal of Business and Social Research, vol. 3: 17-35

Zandi, G., Naysary, B. \& Kwan, S.S. (2013) "The behavioral intention of Malaysian students toward accounting discipline", Accounting and Management Information System, vol. 12: 471-488 